\title{
Utilization of Information and Communication Technology in Teaching and Learning at the Primary School Level: A Developing Country Perspective
}

\author{
Sophia Ruth Morrison ${ }^{1 *} \quad$ Paul Nyagorme $^{1} \quad$ Albert Arthur Qua-Enoo $^{2}$ \\ 1.College of Distance Education, University of Cape Coast, Ghana \\ 2.Institute for Distance \& e-Learning, University of Education, Winneba, Ghana
}

\begin{abstract}
The study was conducted to assess the usage of Information Communication and Technology (ICT) in teaching and learning in primary schools within the OLA Circuit of the Cape Coast Metropolis. Again, the study was done to find out the availability of ICT facilities, efficient and accessible this infrastructure and challenges of integration. The study was carried out in five Government (Public) schools within the OLA Circuit in Cape Coast, Ghana. Descriptive survey was conducted using questionnaires to collect data on 50 teachers. Descriptive and inferential statistical tools such as frequency, correlation and linear regression were used to analyse the data. The findings indicated that teachers teaching in the primary schools were willing to use ICT for their teaching but due to some challenges of inadequate facilities such as computer laboratory, electricity, projectors, scanners, printers and inadequate computer technicians hindering seamless integration of ICT in their teaching and learning. Also, the study showed that teachers had positive perceptions on the benefit of ICT on their teaching. Furthermore, most teachers requested for training in ICT, support services for technology, sufficient software to help sustain their interest in teaching and learning of the subject. It was recommended that technology and technical support unit should be instituted in the various schools to handle technology integration challenges and provide rapid responses to teachers' technological needs.
\end{abstract}

Keywords: Digital divide, E-learning, ICT, ICT Competence, ICT Technology

DOI: $10.7176 / \mathrm{JEP} / 11-33-18$

Publication date: November $30^{\text {th }} 2020$

\section{Introduction}

The rapid developments in technology have made tremendous changes in the way we live, as well as the demands of society.

Recognising the impact of new technologies on the workplace and everyday life, today's educational institutions try to restructure their education programs and classroom facilities, in order to minimize the teaching and learning technology gap between today and the future. This restructuring process requires effective integration of technologies into existing context in order to provide learners with knowledge of specific subject areas, to promote meaningful learning and to enhance professional productivity (Tomei, 2005). Over the years, several initiatives and investments have been made by the government of Ghana in integrating ICT into the educational system (WAEC, 2010). The development of teachers' positive attitudes toward ICT is very significant factor not only for increasing computer integration but also avoiding their resistance to usage (Mansuri, 2017). A growing number of studies have been conducted on teachers' confidence in their use of computers, either for personal work or in their teaching practice. Several studies have reported that teachers were reluctant to reveal their level of computer knowledge to students and were unwilling to use computers in regular teaching practice until they felt comfortable and competent in using the technology. (Cavas et al., 2009; Ndibalema, 2014; Kambagha, 2008).

Teachers with computer experience have better chance of integrating ICT in their teaching process. Successfully planning and

implementing educational technology in the curriculum needs teachers support, attitudes and confidence in their ability to use computers effectively. Teachers with computer experience relate positively to their computer attitudes. Teachers' attitudes toward computers have significant implications for behaviours of teachers in the use of computers for teaching (Kellenberger \& Hendricks, 2003). It is believed that if teachers perceived technology programs as neither fulfilling their own needs nor their students' needs, it is likely that they will not integrate the technology into teaching and learning. The importance teachers place on student effort is complemented by a growing body of research evidence of increased student work output resulting from ICT use. Recent studies have noted marked student productivity improvements as a direct result of ICT usage (Smeets \& Mooij, 2001; Tomie, 2005).

\subsection{Research Question}

The following questions were formulated to guide the study:

1. What is the situation with regard to resources for teachers using ICT? 
2. How is ICT actually being used by teachers?

3. What is the effect of ICT used by teachers on teaching and learning?

4. What are the challenges facing the integration of ICT for learning and teaching at the basic school level?

5. Are there relationships between the integration, challenges, facilities available, computer skills, perception and educational level?

6. What are the effects of gender, highest educational level, computer skills, perception and availability of ICT facilities on ICT integration?

7. What factors actually contribute to the challenges affecting the integration of ICT?

\section{Literature Review}

The following areas were reviewed under study: policy of ICT education in Ghana, ICT use in Education, benefits of ICT use in Education, factors influencing the implementation of ICT, ICT Facilities accessibility to pupils and teachers, courseware development, training, technical and pedagogical support, impact on the role of the teacher, teacher characteristics, access and use of common ICT tools, confidence in using ICT, student characteristics, school support and ICT teaching issues, challenges and obstacles, beliefs about students work and effort using ICT, planned learning objectives and outcomes, and effect of ICT on teaching and learning.

Policy of ICT Education in Ghana: Government of Ghana is committed to the transformation of the agrobased economy of Ghana into an information rich and knowledge - based economy and society using the tools of information and Communication Technology (ICT). The Ministry of Education and its agencies such as Ghana Education Service at the Regional and District levels are responsible for the administration and implementation of provision and the delivery of education and training at all levels within the education system of Ghana (Draft Copy of ICT policy, 2006).

ICT use in Education: Placing computers in classrooms rather than separate computer laboratories enables much greater use of ICTs for 'higher order' skills. Indeed, a smaller number of computers in classrooms may enable more actual use than a greater number of computers located in separate computer labs. Related to this is an increasing amount of attention, given by both teachers and students, to the use of laptops (and in some places, 'computers-on-wheels'). To a much lesser extent, the use of personal digital assistants and other mobile devices are useful learning aids in the classroom. (Akkerman \& Filius, 2011). ICTs can promote learner autonomy (Alonazi, 2017).

Benefits of ICT use in Education: Early advocates of ICT integrated education saw it as a catalyst for change, fostering skills in problem solving and critical thinking as well as the development of pupil centered learning (McGrail, 2005). ICT makes knowledge acquisition more accessible, and concepts in learning areas are understood while engaging pupils in the application of ICT (Brush, Glazewski \& Hew, 2008). The use of technology in the learning environment has become an unstoppable force in recent years (Cohen, Manion \& Morrison 2004; Laubsch, 2006). ICT impacts on a large section of education, from record keeping and school websites to the creation of online learning communities (Bishop, 2007). Educational institutions can use specialized websites to make learning resources available online at any time. Some educational institutions do not even require pupils to be physically present. Virtual classrooms have flourished in tandem with improved internet accessibility. The significant barriers of time and distance are rendered almost obsolete in such virtual classrooms (Stennes, 2008).

Factors Influencing the Implementation of ICT: Important factors at the community level that may stimulate the implementation of ICT in classroom practice are ICT facilities and accessibilities to pupils and teachers, financial support, courseware development and teacher training. Another aspect which is crucial is the position of ICT in the curriculum. These factors depend to a large extent upon the government policy towards ICT in education.

ICT Facilities and Accessibility to Pupils and Teachers: Availability of ICT infrastructure is an important variable of ICT integration in schools. A doctoral dissertation by Ottesen (2006) revealed that one fundamental problem facing ICT integration in schools is the lack of computer infrastructure. In a related study, with time to work on their professional development with regard to the use of ICT. Funding is also necessary in order to give the teachers support by a computer co-ordinator, as well as for the maintenance of hardware. The provision of hard- and software to schools may also be interpreted as financial support.

Courseware Development: Several authors have stressed the importance of courseware fitting into the curriculum (Mooij, 2004; Hirst, Brooks \& Riddle, 2004). The question to what extent software is produced which fits into the curriculum, is - especially in the non-English speaking countries - to a large part determined by national factors. Smeets \& Mooij (2001) stated that it is necessary for governments to fund softwares for developmental coursewares.

Training, Technical and Pedagogical Support: Professional development is an important issue with regard to the use of ICT in education. Kere (2016) identified a correlation between teachers' knowledge and attitude of Norris, Sullivan and Poirot, (2003) revealed that appropriate access to technology infrastructure is another key factor in the effective technology integration process. The study revealed substantive correlation between technology access and use. In another study, Yildrim (2007) revealed that teachers agreed that access to ICT 
infrastructure is one of the effective means to integrate ICT in classrooms.

Financial Support: In order to provide schools with an adequate basis for the implementation of ICT, funding is necessary. Schools have to be able to acquire suitable ICT-supported hardware, software, internet, audio visual aids, teaching aids and other accessories. They also have to be able to provide their teachers with training and teachers and access to ICT facilities. He advocated in-service training, workshops and seminars for ICT teachers should be organized to inculcate positive attitude in them. The European Commission's Task Force Educational Software and Multimedia points out that the provision of training and information to teachers is a pre-condition for the development of pedagogic uses for multimedia (European Commission, 1996). Cox, Preston and Cox (2009) noted that the perceived usefulness of computers to teaching is pertinent and needs inclusion in training teachers.

Impact on the Role of the Teacher: The teachers' role in the classroom can be viewed as a continuum. At one end is the teacher as a traditional lecturer and importer of knowledge. This is in accordance with objectivist views of learning. At the other end is the teacher as a coach, observer, and facilitator. Teaching in pupil-centred learning environments requires a different attitude of the teacher than teaching in traditional instructional settings. Teachers are expected to move to facilitating individualized, interactive, media-based learning, stimulating their pupils to accept far greater responsibility for their own learning.

Teacher Characteristics: Personal characteristics of teachers have been identified in research on predictors of exemplary teaching practice and computer use. Factors common to many studies examining predictors of teachers' ability to implement computer-based instruction include teacher gender, grades taught, years of teaching experience, training and experience in teaching with ICT and computer ownership (Cubukcuoglu, 2013; ChanLin et al., 2006; Smeets \& Mooij, 2001). The lack of experienced ICT-using teachers, both male and female, however, is a common theme throughout the literature locally and abroad (Barrette, 2001; Clarke, 2001; Crook, 2001; Czernezkyj, Fagan, Forster, Littler, Richards, \& Watkins, 2001).

Access and Confidence in Using ICT: Researchers have identified a correlation between regular use of ICT and confidence in using it to teach (Guha 2000; Cox, Preston \& Cox 2009; Ross, Hogaboam-Gray and Hannay, 2009). The perceived usefulness of ICT spawn adoption of ICT integration (Yuen \& Ma, 2002). A growing number of studies have been conducted on teachers' confidence in their use of computers, either for personal work or in their teaching practice. Several studies (Bandura, 2002, Becta 2003; Ross, Hogaboam-Gray and Hannay, 2009; Ninlawan, 2015) reported that teachers were reluctant to reveal their level of computer knowledge to students and were unwilling to use computers in regular teaching practice until they felt comfortable and competent in using the technology. Teachers with more computer experience had greater confidence in their ability to use computers effectively (Peeraer \& Van Petegem, 2009; Hismanoglu, 2012).

Student Characteristics: Under much investigation in educational research are the influences of antecedent factors, those of student gender, age and language background. A key finding of a review of literature conducted by the Victorian Curriculum and Assessment Authority (2002) stated: There are many factors that impact on a student's ICT skill level, including: gender, indigeneity, enrolment across different school sectors, location in terms of urban and rural, enrolment in small and large schools and family income (VCAA, 2002, p.80). A significant research focus on gender and ICT in the areas of literacy and numeracy was identified by Blackmore, Hardcastle, Bamblett \& Owens, (2003).

School Support and ICT Teaching Issues, Challenges and Obstacles: Although whole school engagement in a democratic and structured process of adoption has been shown to be the most effective way to embed ICT curriculum wide, research has revealed many barriers that hinder progress. A study conducted by Organisation for Economic Cooperation Development (OECD) in 2009 and cited in Rodden (2010) confirmed that there are a number of barriers or challenges that inhibit the use of ICT in education. These barriers included an inconsistent number of computers to pupils, a deficit in maintenance and technical assistance and finally, a lack of computer skills and/ or knowledge among teachers (Nihuka \& Voogt, 2011)

Beliefs about Students Work and Effort Using ICT: Many years of research into school improvement and effectiveness have shown that improving the educational outcomes of students requires changing belief and value systems of teachers throughout the school (Harris \& Bennett, 2001). Teachers' educational beliefs are strong indicators of their planning, instructional decisions and classroom practices investigated teachers' instructional computer use and found that motivating students' interest in school work was an important factor (Mwalongo, 2011; Palak \& Walls (2009). Recent studies (Smeets \& Mooij, 2001; Tolmie, 2005; Ndibalema, 2014) have noted marked student productivity improvements as a direct result of ICT usage.

Planned Learning Objectives and Outcomes: Most researchers highlight the need to plan carefully the use of ICT in lessons. Sutherland (2004) sum this up as "ICT alone does not enhance learning, how ICT is incorporated into learning activities is what is important". Abbott (2001) also stress the importance of detailed lesson planning when using ICT and that, pupils must be encouraged to understand the process involved rather than simply focusing on the output. Some teachers may use ICT as a way of encouraging independent learning skill but their use needs to be planned and supervised with the teacher directing the Pupil's activities and outputs ICT though as an effective tool in the hands of an effective teacher, and not a panacea in its own right. It would seem that 
prerequisite for success is the subject knowledge of the teacher and his ability to weave the use of ICT into the existing curriculum.

Effect of ICT on Teaching and Learning: Technology has changed the way people live, work and learn. The use of technology in education is one of the main challenges for education policy makers (Zalzadeh, 2006). Traditional methods of education are no longer able to meet the needs of today's learners. New technologies provide opportunities including the ability to tailor learning to the individual (Aminpour, 2007). The influence that IT can have on teaching methods depends on the knowledge and skills of students and teachers, and the implementation of IT and ICT in courses (Kusha 2006).

\section{Methodology}

The research methodology outlined and explained the relationships between the research problems, the data collecting instruments and the analysis of the research.

Research Design: Descriptive survey design was employed for the study. The study explored the effect of using ICT on teaching and learning in the primary schools within the OLA Circuit in the Cape Coast Metropolis of Ghana. The populations of the study were all teachers of the OLA circuit basic schools in Cape Coast. In all fifty (50) people were chosen to represent the total population. Random samplings were used to select teachers from the selected schools for the study.

Methods of Data Collection: Primary and Secondary methods of data collection were used. The primary data was collected using questionnaire while the secondary data was gathered from the literature.

Research Instrument: Questionnaire as the research instrument was used to gather data to answer the questions set for this study. This research instrument took less time to administer them and also ensured the confidentiality of respondents. Teachers were given a form of questionnaire which consisted of close and open-ended items.

Data Analysis: The data collected were sorted, organised, coded and entered into the computer and analysed with the aid of Statistical Package for Social Sciences (SPSS Version 21.0). Both descriptive and inferential statistics were used for the analysis and discussion of data collected from the field. Frequencies, percentages, correlation and regression were used for analysing the data. The data was presented using tables.

\section{Results}

In assessing the effect of using ICT in teaching and learning in primary schools, the study focused on the situation with regard to resources and support for teachers using ICT, how is ICT actually being used by teachers, the effect of ICT used by teachers on teaching and learning, challenges encountered and ways that can be used to improve the ICT learning and teaching at the primary level. Tables were used to support the research findings.

Table 1. Name of School

\begin{tabular}{|c|c|c|}
\hline School & Frequency & $\begin{array}{l}\text { Percentage } \\
(\%)\end{array}$ \\
\hline OLA Presby Primary & 11 & 22.0 \\
\hline Apewosika M/A (A) Primary & 9 & 18.0 \\
\hline Kwaprow M/A Primary & 13 & 26.0 \\
\hline AbakamCran Presby Primary & 8 & 16.0 \\
\hline Amamoma Presby Model Primary & 9 & 18.0 \\
\hline Total & 50 & 100.0 \\
\hline \multicolumn{3}{|c|}{$\begin{array}{l}\text { From Table 1, the number of teachers who were within the OLA Presby primary school was } 11(22.0 \%) \text { out } \\
\text { of total number of } 50 \text { teachers. Again, } 9(18.0 \%) \text { of the teachers were from Apewosika M/A primary school. } 13 \\
(26.0 \%) \text { of the teachers were also from Kwaprow M/A Primary school. AbakamCran Presby primary had a number } \\
\text { of } 8(16.0 \%) \text { of teachers coming from its school. The last category of Amamoma Presby Model Primary school } \\
\text { had } 9(18.0 \%) \text { of teachers. From the above Table, it can be clearly seen that the majority of the teachers were from } \\
\text { Kwaprow M/A primary school, } 13(26.0 \%) \text {. } \\
\text { Table 2: Gender of Respondents }\end{array}$} \\
\hline & Frequency & Percentage (\%) \\
\hline Male & 15 & 30.0 \\
\hline Female & $\underline{35}$ & $\underline{70.0}$ \\
\hline Total & 50 & 100.0 \\
\hline
\end{tabular}

Table 2 sought to elicit information on the sex analysis of teachers in the study. The data revealed that out of the 50 sampled teachers, $15(30.0 \%)$ of them were males and $35(70.0 \%)$ constituted females. 
Table 3: Highest Educational Level Attained

\begin{tabular}{lcr}
\hline \multicolumn{1}{c}{ "O/'A' Level } & Frequency & Percentage (\%) \\
Diploma & 2 & 4.0 \\
Post Diploma/Degree & 16 & 32.0 \\
Masters/PHD & 27 & 54.0 \\
Total & 5 & 10.0 \\
\hline
\end{tabular}

Table 3 showed that, 2 (4.0\%) of the teachers had an O/A Level, 16 (32.0\%) of teachers had a diploma, while $27(54.0 \%)$ of teachers had a post diploma/Degree. Again, 5(10.0\%) of teachers had Masters/PHD. The qualification distribution shows a lean percentage of two teachers having an $\mathrm{O} / \mathrm{A}$ Level certificate.

As indicated in Table 4 below, among 50 teachers, 23(46.0\%) had a teaching experience of 3-10 years. For the remaining 27 teachers, $17(34.0 \%)$ out of the remaining also had a teaching experience of 11-20 years. Again $10(20.0 \%)$ of the rest of the teachers had a teaching experience of 21 and above.

Table 4: Number of Years of Teaching

\begin{tabular}{lcr}
\hline & Frequency & Percentage $(\mathbf{\%})$ \\
\hline 3-10 Years & 23 & 46.0 \\
$11-20$ Years & 17 & 34.0 \\
21 and above Years & 10 & 20.0 \\
Total & $\mathbf{5 0}$ & $\mathbf{1 0 0 . 0}$ \\
\hline
\end{tabular}

\section{Discussions}

Research Question 1: What is the situation with regard to resources for teachers using ICT?

Research question 1 examined the availability of ICT facilities to teachers in the teaching of ICT in primary school. It examines resource materials needed for teaching and learning of ICT in primary schools. For easy analysis, Strongly Agree (SA) and Agree (A) were grouped as "SA/A", Not Sure was designated as "Indecisive" and both Strongly disagree (SD) and Disagree (D) as Disagree "D". This is presented in Table 5. $42(84.0 \%)$ teachers indicated that they have electricity connectivity in their schools. However, $8(16.0 \%)$ teachers indicated that their school do not have electricity connectivity in their schools. Electricity connectivity is a basic necessity for the implantation of ICT curriculum in schools. This was confirmed when the same number $42(84.0 \%)$ teachers whom indicated the availability of electricity in schools indicated that they have computers in their school computer laboratory/library.

On the issue of internet facility in the computer laboratory/library, majority $30(60.0 \%)$ teachers indicated that their schools have internet access at their computer laboratory/library. However, $20(40.0 \%)$ teachers indicated that their schools don't have internet access in their computer laboratory/library. Internet access is needed in schools to help in the teaching and learning.

Table 5: ICT Facilities Available in Primary Schools

\begin{tabular}{|c|c|c|c|c|c|c|}
\hline & \multicolumn{2}{|c|}{ SA/A } & \multicolumn{2}{|c|}{ Indecisive } & \multicolumn{2}{|c|}{ SD/D } \\
\hline & $\overline{\mathbf{N}}$ & $\%$ & $\mathbf{N}$ & $\%$ & $\mathbf{N}$ & $\%$ \\
\hline We have electricity at the school premises & 42 & 84.0 & - & - & 8 & 16.0 \\
\hline We have computers in the school lab/library & 42 & 84.0 & - & - & 8 & 16.0 \\
\hline We have Internet access in the computer lab/library & 20 & 40.0 & - & - & 30 & 60.0 \\
\hline We have printer at the school computer lab/library & 20 & 40.0 & - & - & 30 & 60.0 \\
\hline We have scanner at the school computer lab/library & 20 & 40.0 & - & - & 30 & 60.0 \\
\hline There is a projector installed to aid teaching and learning of ICT & -- & -- & - & - & 50 & 100 \\
\hline Computer lab has the required softwares for teaching and learning & 20 & 40.0 & - & - & 30 & 60.0 \\
\hline Recommended ICT books/magazines available for teaching and & 42 & 84.0 & - & - & 8 & 16.0 \\
\hline
\end{tabular}

learning

In the case of whether teachers have printer and scanner at their school computer laboratory/library, $30(60.0 \%)$ teachers indicated that they have printer and scanner at their school computer laboratory/library respectively. However, $20(40.0 \%)$ teachers indicated that they don't have printer and scanner at their school computer laboratory/library respectively.

In respect to projector installed in computer laboratory, all $50(100.0 \%)$ teachers indicated that their schools do not have projector installed to aid in teaching and learning of ICT. Also, $30(60.0 \%)$ teachers indicated that their schools do not have required software installed to support the teaching and learning of ICT. Schools are not provided with original Microsoft product such as Microsoft operating system and office suite including other application software like Mavis Beacon and Encarta.

Lastly, $42(84.0 \%)$ indicated that they have recommended ICT textbooks and syllabus to support teaching and learning of ICT. However, $8(16.0 \%)$ teachers indicate that their schools do not have recommended ICT 
textbooks and syllabus available in their schools to support the teaching and learning of ICT. ICT textbooks and syllabus are needed by teachers and students for smooth implementation of the ICT curriculum.

Research Question 2: How is ICT actually being used by teachers?

Research question 2 examined how teachers actually integrated ICT in teaching. To know the level of ICT integration of teachers in teaching, research question 13 to 17 of the teachers' questionnaire was used.

Teachers $42(84.0 \%)$ who indicated to have computers at their computer laboratory/library, were asked the hours per week they get the chance to use their computer laboratory.

Table 6: Hours per Week Permissible to Use the Computers in the School

\begin{tabular}{lcc}
\hline & Frequency & Percentage (\%) \\
\hline Less than an hour & 9 & 18.0 \\
$1-3$ hours & 33 & 66.0 \\
\hline Total & $\mathbf{4 2}$ & $\mathbf{8 4 . 0}$
\end{tabular}

From Table 6, majority $33(66.0 \%)$ teachers indicated that they get 1-3 hours in a week to use their computer laboratory. Nine $(18.0 \%)$ teachers indicated that they are given less than hour for the use of their computer laboratory. Teachers were asked if they are able to integrate ICT in their teaching. Their response was presented in Table 7.

Table 7: Teachers Integration of ICT in Teaching

\begin{tabular}{lrr}
\hline \multicolumn{1}{c}{ Yes } & Frequency & Percentage (\%) \\
\hline No & 36 & 72.0 \\
Total & 14 & 28.0 \\
\hline
\end{tabular}

From Table 7, $36(72.0 \%)$ teachers indicated that they employ ICT in their teaching. However, $14(28.0 \%)$ teachers indicated that they are not able to integrate ICT in their lesson delivery.

Teachers were asked to indicate whether they used ICT in preparing continues assessment for their students.

In Table 8, $30(60.0 \%)$ teachers indicated that they use ICT in preparing continuous assessment for their pupils. ICT tools like Microsoft excel sheet was employed in the preparation of continuous assessment of pupils. However, $20(40.0 \%)$ teachers indicated that they were not able to integrate ICT in continuous assessment of pupils. Table 8: Teachers Integration of ICT Continuous Assessment

\begin{tabular}{lrr}
\hline & Frequency & Percentage (\%) \\
\hline Yes & 30 & 60.0 \\
No & 20 & 40.0 \\
Total & $\mathbf{5 0}$ & $\mathbf{1 0 0 . 0}$ \\
\hline
\end{tabular}

Teachers were also asked to indicate whether they integrate ICT in preparing terminal/performance reports of their pupils. Teachers' response to this is presented in Table 9.

Table 9: Teachers Integration of ICT in Reports on Performance of Pupils

\begin{tabular}{lrrr}
\hline \multicolumn{1}{c}{ Yes } & Frequency & Percentage (\%) \\
No & 32 & 64.0 \\
Total & 18 & 36.0 \\
\hline
\end{tabular}

From Table 9, 32 (64.0\%) teachers indicated that they do employ ICT in preparing performance reports of their pupils. Reports of student's performance is easily done when ICT tools are employed. ICT tools can be used to easily rank students into positions as well as in measuring their performance which are used in generating terminal reports for pupils. However, $18(36.0 \%)$ teachers indicated that they are not able to employ ICT in preparing performance reports of their pupils.

In order to know how teachers employ ICT in teaching, the following questions on use of ICT in teaching were asked. Note for easy analysis, Strongly Agree (SA) and Agree (A) were grouped as Agree, Don't Know and Strongly disagree (SD) and Disagree (D) as Disagree. Teacher responses are presented in Table 10.

From Table 10 below, 28 (56.0\%) teachers indicated that they don't use internet to search for information in preparing lesson notes. In relation to the syllabus, teachers can use the internet to know new methods of some lesson delivery and also immerging ideas in related content fields. However, 22 (44.0\%) of teachers indicated that they employ the use of the internet in searching for more information for preparing notes for lessons.

On the issue of whether teachers use Ms Word in preparing teaching and learning activity, $41(82.0 \%)$ teachers indicated that do not use Ms Word in the preparation of teaching and learning materials for pupils. Also, $41(82.0 \%)$ teachers indicated that they do not use the printer as ICT tool in printing exams papers. When pupils' exams questions are typed using Ms Word and printed, it helps in better presentation of exams question than writing them on the blackboard. It also helps the teacher set questions across many areas since the blackboard is able to take a few questions at a time. 
Table 10: Teachers Use of ICT in Teaching

\begin{tabular}{|c|c|c|c|c|c|c|}
\hline & \multicolumn{2}{|c|}{ Agree } & \multicolumn{2}{|c|}{ Don’t Know } & \multicolumn{2}{|c|}{ Disagree } \\
\hline & $\mathbf{N}$ & $\%$ & $\mathbf{N}$ & $\%$ & $\mathbf{N}$ & $\%$ \\
\hline I use the internet to search for Information in preparing notes & 22 & 44.0 & - & - & 28 & 56.0 \\
\hline I use MS Word in typing additional notes for pupils & 9 & 18.0 & - & - & 41 & 82.0 \\
\hline $\begin{array}{l}\text { I use MS Word in preparing \& printing handouts/textbooks for } \\
\text { pupils }\end{array}$ & 9 & 18.0 & - & - & 41 & 82.0 \\
\hline I use the printer in printing exams papers for pupils & 9 & 18.0 & - & - & 41 & 82.0 \\
\hline I employ excel in analysing my class performance & 11 & 22.0 & - & - & 39 & 78.0 \\
\hline I employ excel in the Continuous Assessment of my class & 10 & 20.0 & - & - & 40 & 80.0 \\
\hline I use Ms Word in reporting writing & 18 & 36.0 & - & - & 33 & 66.0 \\
\hline I use the PowerPoint to make presentations & 12 & 24.0 & - & - & 38 & 76.0 \\
\hline
\end{tabular}

Furthermore, $40(80.0 \%)$ teachers indicated that they do not use excel in doing continuous assessment of their class. Excel helps in easy tabulation and also helps the teacher get a proper pictorial view of pupils' performance. However, $10(20.0 \%)$ teachers indicated that they use excel in preparing continuous assessment for their class.

In relation to using Ms Word in reporting writing, 33 (66.0\%) teachers do not use Ms Word in writing report of their pupils. Nevertheless, 18 (36.0\%) of teacher indicated that they are able to use Ms Word in writing report of the pupils. Lastly, $38(76.0 \%)$ indicated that they are able to use PowerPoint in making presentations.

Research Question 3: What are teachers' perceived benefit of ICT in teaching?

Teachers' perceived benefit of integrating ICT in their teaching and their responses is presented in Table 11. 38 $(76.0 \%)$ teachers perceive that integrating ICT in teaching does not make the lesson more interesting. Contrary, $12(24.0 \%)$ perceive that employing ICT tools in teaching makes lesson interesting. Also, $29(58.0 \%)$ teachers perceive that using ICT in teaching makes lesson enjoyable but $34(68.0 \%)$ teachers disagree that using ICT in lesson makes lesson more fun.

Table 11: Teachers Perceived Benefit of Integrating ICT in Teaching

\begin{tabular}{|c|c|c|c|c|c|c|}
\hline \multirow[t]{2}{*}{ Responses } & \multicolumn{2}{|c|}{ Agree* } & \multicolumn{2}{|c|}{ Don't Know } & \multicolumn{2}{|c|}{ Disagree** $^{* *}$} \\
\hline & $\overline{\mathbf{N}}$ & $\%$ & $\mathbf{N}$ & $\%$ & $\mathbf{N}$ & $\%$ \\
\hline Using ICT makes my lesson more interesting & 12 & 24.0 & - & - & 76.0 & 38.0 \\
\hline Using ICT in my teaching is not enjoyable & 29 & 58.0 & - & - & 21 & 42.0 \\
\hline Using ICT makes my lesson more fun & 16 & 32.0 & - & - & 34 & 68.0 \\
\hline Using ICT makes my lesson more diverse & 20 & 40.0 & 10 & 20.0 & 20 & 40.0 \\
\hline Using ICT improves my presentation of materials & 16 & 32.0 & 12 & 24.0 & 22 & 44.0 \\
\hline Using ICT makes my lesson more difficult & 16 & 32.0 & 3 & 6.0 & 31 & 62.0 \\
\hline Using ICT reduces pupils' motivation & 10 & 20.0 & 3 & 6.0 & 37 & 74.0 \\
\hline Using ICT impairs my pupils' learning & 8 & 16.0 & 2 & 4.0 & 40 & 80.0 \\
\hline
\end{tabular}

*Strongly agree and Agree $\quad * *$ Strongly disagree and Disagree

Twenty $(40.0 \%)$ teachers agree and disagree respectively when it comes to the issue of using ICT in teaching making lesson more diverse. On the issue of using ICT in teaching improving presentation of teaching materials, $22(44.0 \%)$ teachers perceive that ICT does not improve the presentation of materials. Twelve $(24.0 \%)$ teachers were indecisive to using ICT improving presentation of materials.

From Table 11, $31(62.0 \%)$ teachers perceive that using ICT in teaching makes lesson less difficult. Also, 37 $(74.0 \%)$ teachers perceive that using ICT in teachers does not reduce pupils' motivation level. However, 40 (80.0\%) teachers perceive that using ICT does not impair their pupils' learning.

Research Question 4: What challenges are facing the integration of ICT into teaching and learning at the primary level?

Research question 4 examines the challenges facing the integration of ICT in teaching and learning at the primary school level. Teachers' responses are presented in Table 12.

From Table 12 on challenges facing primary schools on integration of ICT in primary schools, $50(100.0 \%)$ teachers indicated that the availability of computers and adequacy of the computers if available respectively affect them. Computer is one of the most important equipment needed for implementation of ICT in primary schools. However, if available, its adequacy also poses a challenge to teaching and learning of ICT in primary schools. 
Table 12: Challenges Facing the Integration of ICT into Teaching and Learning

\begin{tabular}{|c|c|c|c|c|c|c|}
\hline \multirow[t]{2}{*}{ Challenges } & \multicolumn{2}{|c|}{ Agree* } & \multicolumn{2}{|c|}{ Don't Know } & \multicolumn{2}{|c|}{ Disagree $* *^{*}$} \\
\hline & $\mathbf{N}$ & $\%$ & $\mathbf{N}$ & $\%$ & $\mathbf{N}$ & $\%$ \\
\hline Availability of computers & 50 & 100 & - & - & - & - \\
\hline Adequate computers per pupils & 50 & 100 & - & - & - & - \\
\hline Maintenance of available computers & 48 & 96 & - & - & 2 & 4.0 \\
\hline Technical support & 40 & 80.0 & - & - & 10 & 20.0 \\
\hline Level of teachers' ICT knowledge and skills & 7 & 20.0 & - & - & 43 & 86.0 \\
\hline Unavailability of adequate power supply & 50 & 100 & - & - & - & - \\
\hline Absence of internet access & 39 & 78.0 & 3 & 6.0 & 8 & 16.0 \\
\hline
\end{tabular}

*Strongly agree and Agree $\quad * *$ Strongly disagree and Disagree

Forty-three $(86.0 \%)$ teachers disagree to the question asking whether the level of teachers' knowledge and skills in ICT do pose as a challenge for the integration of ICT in primary schools. During the training of teachers, pre-teachers are taking through ICT as a course to enable them teaches ICT in primary schools. Also, the ministry of education through Ghana Education Service provide in-service training for teachers in the teaching of ICT. However, the unavailability of adequate power supply was indicated by all the respondents, $50(100.0 \%)$ teachers, as the major challenge facing the integration of ICT in teaching and learning in primary schools. Also, to $39(78.0 \%)$ teachers indicated that the unavailability of internet access in school affect the integration of ICT in the teaching and learning in primary schools within the OLA circuit of the Cape Coast Metropolis.

Research Question 5: Are there relationships between the integration, challenges, facilities available, computer skills, perception and educational level?

Table 13: Correlations

Integration has a relationship with challenges Pearson Correlation Coefs. (r) Sig (2-tailed) Integration has a relationship with perception $-.27$ .051

Integration has a relationship with skills .096 .505 Integration has a relationship with facilities $.915 \quad .000$

Facilities have a relationship with perception .096

Facilities have a relationship with skills

$-.070$

.631

Facilities have a relationship with integration

.017

Facilities have a relationship with challenges

.096 .509

Perception has a relationship with challenges .864

Perception has a relationship with skills

The Pearson product moment correlation was utilized to find out the interrelationship between ICT integration, ICT challenges, skills possessed by teachers, ICT facilities available and teachers' perception of ICT integration in table 13. At the p-value of 0.05 (5\% confidence level), there was a strong positive relationship $(\mathrm{r}=0.915)$ between ICT integration and computer literacy of the teachers. For the rest of the variables in table 15, the relationships among the variables were statistically insignificant $(\mathrm{p}>0.05)$, were made up of positive and negative correlation when their $r$ values were observed. Yuksel \& Kavanoz (2011), found a close link between attitude, usage and perception of ICT integration. ICT integration was found to correlate negatively with ICT challenges, the relationship between available ICT facilities and perception challenges; and that of educational level and computer skills were found to follow the same trend. Talua, Pelingon, and Verecio (2016) stated that age, teaching experience, and ICT training in computer schools are socio-demographic variables consistent to have significant relationship with attitude toward ICT, computer self-efficacy and level of ICT competency.

Research Question 6: What are the effects of gender, highest educational level, computer skills, perception and availability of ICT facilities on ICT integration?

The effects of gender, highest educational level, computer skills, perception and availability of ICT facilities on ICT integration are presented in in a regression analysis in Tables $14 \mathrm{a}, 14 \mathrm{~b}$ and $14 \mathrm{c}$ below.

\section{Table 14a: Model Summary}

\begin{tabular}{lllll}
\hline Model & R & R Square & Adjusted R Square & Std. Error of the Estimate \\
\hline 1 & $.490 \mathrm{a}$ & .240 & .153 & 1.532 \\
$\begin{array}{l}\text { a. Predictors: (Constant), Highest Educational Level attained, Total Skills, Total ICT Perception, Total ICT } \\
\text { facilities, Gender }\end{array}$
\end{tabular}


Table 14b: ANOVA ${ }^{a}$

\begin{tabular}{lllllll}
\hline Model & & $\begin{array}{l}\text { Sum of } \\
\text { Squares }\end{array}$ & df & $\begin{array}{l}\text { Mean } \\
\text { Square }\end{array}$ & F & Sig. \\
\hline \multirow{2}{*}{1} & Regression & 32.601 & 5 & 6.520 & 2.777 & $.029^{\mathrm{b}}$ \\
& Residual & 103.319 & 44 & 2.348 & & \\
& Total & 135.920 & 49 & & & \\
\hline
\end{tabular}

a. Dependent Variable: Total ICT Integration

b. Predictors: (Constant), Highest Educational Level attained, Total Skills, Total ICT Perception, Total ICT facilities, Gender

Table 14c: Coefficients ${ }^{a}$

\begin{tabular}{llllll} 
Model & \multicolumn{3}{c}{ Unstandardized Coefficients } & Standardized Coefficients & t \\
\cline { 2 - 5 } & B & Std. Error & Beta & & \\
\hline (Constant) & 2.899 & 2.874 & & 1.009 & .319 \\
Facilities & .199 & .087 & .309 & 2.289 & .027 \\
Perception & .240 & .154 & .211 & 1.556 & .127 \\
$1 \quad$ Skills & .372 & .144 & .342 & 2.589 & .013 \\
Gender & -.259 & .494 & -.072 & -.524 & .603 \\
\multicolumn{1}{c}{ Educational Level } & -.073 & .318 & -.031 & -.229 & .820 \\
\hline
\end{tabular}

\section{a. Dependent Variable: Integration}

The R Square value shows that $24.0 \%$ of the regression model is predicted by the independent variables in Table 14a. The pvalue of the F statistics (2.777) for the regression model is significant $(\mathrm{p}<0.05)$ from Table $14 \mathrm{~b}$. Table 14c reveals that only two out of the five independent variables (availability of ICT facilities and computer skills) significantly predicted ICT integration in the primary schools surveyed. The ICT skills of teachers were also found to significantly predict ICT integration.

Research Question 7: What factors actually contribute to the challenges affecting the integration of ICT?

The factors actually contribute to the challenges affecting the integration of ICT in the selected schools are presented in the tables below.

Regression Analysis Table 15a: Model Summary

\begin{tabular}{lllll}
\hline Model & $\mathbf{R}$ & R Square & Adjusted R Square & Std. Error of the Estimate \\
\hline 1 & $.980^{\mathrm{a}}$ & .960 & .956 & .120 \\
\hline
\end{tabular}

a. Predictors: (Constant), Absence of internet access, Technological assistant for maintenance of computers, Maintenance of available computers, Level of teachers' ICT knowledge and skills

Table 15b: ANOVA ${ }^{\mathrm{a}}$

\begin{tabular}{llccccc}
\hline Model & & Sum of Squares & df & Mean Square & F & Sig. \\
\hline \multirow{2}{*}{1} & Regression & 15.356 & 4 & 3.839 & 268.091 & $.000^{\text {b }}$ \\
& Residual & .644 & 45 & .014 & & \\
& Total & 16.000 & 49 & & &
\end{tabular}

a. Dependent Variable: Total Challenge to Integration of ICT

b. Predictors: (Constant), Absence of internet access, Technical support, Maintenance of computers, Level of teachers' ICT knowledge and Skills

A further analysis of the factors hindering the integration of ICT among the respondents was done using regression. The predictors included absence of internet access, technical support, maintenance of available computers, level of teachers' ICT knowledge and skills. $96 \%$ of the model was accounted for by the independent variables as displayed by the $\mathrm{R}$ square value in table $15 \mathrm{a}$. The model was statistically significant with $\mathrm{F}$ value of 261,09 as indicated by table $15 \mathrm{~b}$. Table $15 \mathrm{c}$ showed that the regression coefficients all the four independent variables were statistically significant in predicting the challenges to ICT integration in the community. These findings agree with earlier research studies (Mumtaz, 2000; Yildrim, 2007; Hismanoglu, 2012; Cubukcuoglu, 2013; Kere, 2016). 
Table 15c: Coefficients ${ }^{\mathrm{a}}$

\begin{tabular}{|c|c|c|c|c|c|c|}
\hline \multirow{2}{*}{\multicolumn{2}{|c|}{ Model }} & \multicolumn{2}{|c|}{$\begin{array}{l}\text { Unstandardized } \\
\text { Coefficients }\end{array}$} & \multirow{2}{*}{$\begin{array}{l}\text { Standardized Coefficients } \\
\text { Beta }\end{array}$} & \multirow[t]{2}{*}{$\mathrm{t}$} & \multirow[t]{2}{*}{ Sig. } \\
\hline & & B & Std. Error & & & \\
\hline \multirow{5}{*}{1} & (Constant) & 5.019 & .041 & & 121.51 & .000 \\
\hline & Technical support & -.648 & .073 & -.272 & -8.823 & .000 \\
\hline & Maintenance of computers & -.985 & .044 & -.697 & -22.260 & .000 \\
\hline & Teachers' ICT knowledge \& skills & .933 & .054 & .572 & 17.409 & .000 \\
\hline & Absence of internet access & .985 & .039 & .798 & 25.294 & .000 \\
\hline
\end{tabular}

a. Dependent Variable: Total Challenge to Integration of ICT

\subsection{Main Findings}

The major findings of the research question are as follows:

The study found out that inadequate of resources such as computers, computer labs, library, electricity, projectors, scanners, and printers were the major challenges for the successful integration of ICT into teaching and learning in the primary schools with the OLA circuit in Cape Coast. This finding confirmed what Osttensen (2006), revealed that one fundamental problem facing ICT integration in schools is the lack of ICT infrastructures.

The study again found that teachers in the OLA circuit in Cape Coast have positive attitude towards the teaching and use of ICT tools to improve pupils' academic work.

Findings indicated that most teachers within OLA circuit in Cape Coast called for training in ICT to enable them incorporate the tools to all areas of academic work

From the findings, the unavailability of internet access as well as technological assistance for maintenances of available computers in schools affect the integration of ICT in teaching and learning in Primary Schools within the OLA circuit in the Cape Coast Metropolis.

The presence of ICT facilities with computer-trained teachers significantly promote ICT integration in primary schools within the OLA circuit in the Cape Coast Metropolis. According to UNESCO (2002), many educational innovations ultimately fail due to too few resources or effort in teacher preparation.

\subsection{Recommendation for Policy and Practice}

Teacher Education Unit of the Ghana Education Service need to train teachers in new development in ICT. This can be done through in-service training and recommending teachers for distance and sandwich education programmes. Also, teachers should be train in basic computer maintenance so as to help reduce breakdown of ICT facilities.

Government and stakeholders through policy need to provide schools with needed ICT facilities to help in the teaching and learning of ICT. Also, the Ministry of Education through telecom companies can provide internet facilities to all schools. This will also help in the teaching and learning of ICT in schools.

\subsection{Limitations}

There were some drawbacks to this study. The findings of the study were predominantly derived from teachers within the OLA circuit of Cape Coast, Ghana. Secondly, only public-school teachers in the basic schools were involved in this study. Finally, the frequency of females in the study were more than twice the number of males in the study.

\subsection{Recommendation for Future Research}

This study focused on ICT use in within only one of the educational circuits of Cape Coast. A comparative study of ICT usage in basic schools of other circuits within the city or towns with the central region would provide a more detailed integration of ICT in basic schools.

Factors contributing to poor technological infrastructure and lack of mobile devices such as tablets, projectors in classrooms require further research for their minimization.

\section{Conclusion}

The effective use of ICT would require the availability of equipment, supplies of computers and their proper maintenance including other accessories. Besides, ICT requires up-to-date hardware and software. Using up-todate hardware and software resources is a key feature in the diffusion of technology (Gulbahar, 2007). High-speed internet connection is another prerequisite for integrating ICT into the teaching and learning situation.

Based on the findings from the study, teachers and pupils in this study generally have positive attitude towards teaching and learning of information communication technology but due to lack of instructional hardware and software, and high-speed internet connectivity, the use of technology was also narrowed to only ICT lessons instead of incorporating ICT tools in other subject areas. 


\section{References}

Abbott, C. (2001). ICT: Changing education. Psychology Press. London: Routledge.

Aminpour, F. (2007). E-learning in universities and higher education institutions. Faslname-ye ketab, 18(1), $217-$ 228.

Akkerman. S, \& Filius, R. (2011). The Use of Personal Digital Assistants as Tools for Work-Based Learning in Clinical nternships JRTE 43 (4), 325-341.

Alonazi, S. M. (2017). The Role of Teachers in Promoting Learner Autonomy in Secondary Schools in Saudi Arabia.

Canadian Center of Science and Education, English Language Teaching; Vol.10, 7.

Bandura, A. (2002). Self-efficacy mechanisms in human agency. American Psychologist 37, 122-147.

Barrett, H. (2001). ICT supports for electronic portfolios and alternative assessment. Proceedings of the 2001 World Conference for Computers in Education: Networking the Learner, 569-578.

Becta. (2003). Primary schools - ICT and Standards. An analysis of national data from Ofsted an QCA by Becta. Coventry: Retrieved March 2011, from http://www.becta.org.uk/research

Bishop, J. (2007). Increasing participation in online communities: A framework for human -computer interaction. Computers in Human Behaviour, 23(4).1881-1893.

Blackmore, J., Hardcastle, L., Bamblett, E. \& Owens, J. (2003). Effective use of Information Communication and Technology to enhance learning for advantaged school. Institute of disability studies, Dakin University and Institute of Koorie Education. Retrieved on 17 $7^{\text {th }}$ June 2016, from http://www.dest.gov.au/sectors/school_education/publications_resources/profiles/effective.

Brush, T., Glazewski, K. D., \& Hew, K. F. (2008). Development of an instrument to measure preservice teachers' technology skills, technology beliefs, and technology barriers. Computers in the Schools, 25(1-2), 112-125.

Cavas, B., Cavas, P., Karaoglan, B., \& Kisla, T. (2009). A study on science teachers' attitudes toward information and communication technologies in education. TOJET: The Turkish Online Journal of Educational Technology, 8(2). ChanLin, L., Hong, J., Horng, J., Chang, S. and Chu, H. (2006). Factors influencing technology integration in teaching: a Taiwanese perspective. Innovations in Education and Teaching International, ProQuest Education Journals, 43(1), 57-68.

Clarke, B. (2001). Computer Studies in Western Australia. Australian Educational Computing, 16 (1), 48-50.

Cohen, L., Manion, L., \& Morrison, K. (2004). A guide to teaching practice. London: Rutledge.

Cox, M., Preston, C., \& Cox, C. (2009). What factors support or prevent teachers from using ICT in the primary classroom.

Paper presented at the British Educational Research Association Annual Conference. Universe Sussex at Brighton. (September 2-5 2009).

Crook, C. K. (2001). The social character of knowing and learning: Implications of cultural psychology for educational technology. Journal of Information Technology for Teacher Education, 10(1/2), 19-36.

Cubukcuoglu, B. (2013). Factors enabling the use of technology in subject teaching International Journal of Education and Development using Information and Communication Technology (IJEDICT), 9(3), 50-60

Czernezkyj, V., Fagan, K., Forster, M., Littler, M., Richards, A., \& Watkins, R. (2001). Computing Studies in N.T. secondary schools. Australian Educational Computing, 16(1), 24-27

Guha, S. (2000). Are we all technically prepared? Teachers' perspectives on the causes of comfort or discomfort in using computers at elementary grade teaching. Paper presented at the Annual Meeting of the National Association for the Education of Young Children Atlanta, GA.

Harris, Al. \& Bennett, N. (2001). School effectiveness and school improvement: Alternative Perspectives. London and New York: Continuum.

Hirst, D., Brooks, C. \& Riddle, M. (2004). Courseware design and development program: Providing professional development and project experience. In R. Atkinson, C. McBeath, D. Johas-Dwyer \& R. Phillips (Eds), Beyond the comfort zone:

Proceedings of the $21^{\text {st }}$ ASCILITE Conference (pp. 387-394). Perth, 5-8. December. http://www.ascilite.org.au/ conferences/perth04/procs/hirst.html

Hismanoglu, M. (2012). Prospective EFL Teachers' Perceptions of ICT Integration: A Study of Distance Higher Education in Turkey. Educational Technology \& Society, 15(1), 185- 196.

Kambagha, A. H. (2008). Teachers' Perceptions of and Attitudes towards Integrating ICTs in Education: A Case Study of Selected Secondary Schools in Dar es Salaam Region, Tanzania. Thesis submitted to University of Dar es Salaam in partial fulfilment of the requirements for the Master of Arts (Information Studies).

Kellenberger, D., \& S, Hendricks, (2003). Predicting teachers' computer use for own needs, teaching, and student learning. Paper presented at Hawaii International Conference on Education.

Kere, O. D. (2016). Knowledge and Attitude of Teachers' Towards the Teaching of Information and Communication

Technology: A Case Study of Junior High School Teachers' in the Sagnarigu District of Northern Region, Ghana. 
ADRRI Journal of Arts and Social Sciences, Ghana: 14, 4(2), 51-95

Kusha, K. (2006). Educational needs of library and information sciences faculty members in relation with Information and communication technologies (ICT). Faslname-ye ketab, 17(1), 185-214.

Lynch, L., Fawcett, A. \& Nicolson, R. I. (2000). Computer -assisted reading intervention in a secondary school: an evaluation study. British Journal of Education Technology, 31(4), 333-348.

Laubsch, P. (2006). Online and in-person evaluations: A literature review and exploratory comparison. Journal of Online Learning and Teaching, 2(2), 62-73.

Mansuri, L. (2017). Attitude towards Information Technology: a study of Secondary school teachers. Scholarly Research Journal for Interdisciplinary Studies.4(35), 6486-6493.

Mereku, D. K., Yidana, I, Hordzi, W., Tete-Mensah, I., Tete-Mensah, W., \& Williams, J. B. (2009). Ghana PanAfrican Report. University of Education, Winneba, Ghana.

McGrail, E, (2005). Teachers, Technology and Change: English Teacher's Perspectives. Journal of Technology and teacher Education, 13, 5-25.

Mooij, T. (2004). Optimising ICT effectiveness in instruction and learning: multilevel transformation theory and a pilot project in secondary education. Computers \& Education, 42(1), 25-44. Mumtaz, S. 2000. "Factors Affecting Teachers' Use of Information and Communications Technology: a review of the literature". Journal of Information Technology for Teacher Education, (3), 319-341.

Ndibalema, P. (2014). Teachers' Attitudes towards the Use of Information Communication Technology (ICT) as a Pedagogical Tool in Secondary Schools in Tanzania: The Case of Kondoa District. International Journal of Education and Research. 2(2), 1-16.

Ninlawan, G. (2015). Factors which affect teachers' professional development in teaching innovation and Education educational technology in the 21. Century under the Bureau of Special Education, Office of the Basic Commission. Procedia - Social and Behavioral Sciences, 197, 1732 - 1735.

Norris, C., Sullivan, T., \& Poirot, J. (2003). No access, no use, no impact: Snapshot surveys of educational technology in K-12. Journal of Research on Technology in Education, 36(1), 15-27.

Ottesen, E. (2006). Learning to teach with technology: authoring practice identities. Technology, Pedagogy and Education, 15(3), 275-290.

Peeraer, J., \& Van Petegem, P. (2009). The Use of ICT in Teaching Practice in Teacher Education in Vietnam: Baseline Situation at the Start of 'The Year of ICT'. Unpublished Scientific paper. University of Antwerp.

Ross, J., Hogaboam-Gray, A., \& Hannay, L, (2009). Predictors of teachers' confidence to implement computerbased instruction. Journal of Educational Computing Research, 21 (1), 75-97

Rodden, N.B. (2010). An investigation into the barriers Associated with ICT use in the Youth Reach Classroom. A Case study of a centre for Education in the Northwest. University of Limesick.

Smeets, E., \& Mooij, T. (2001). Pupil - centred learning, ICT, and teacher behaviour: Observations in educational practice. British Journal of Educational Technology, 32(4), 403-417.

Stennes, B. (2008). Advantages and disadvantages of web-based learning. Resources Unlimited. Retrieved on $15^{\text {th }}$ June, 2016, from: http://www.resourcesunlimited.com/Advantages_and_Disadvantages_of_ Webbased_Learning.asp.

Sutherland, R. (2004). Designs for learning: ICT and knowledge in the classroom. Computers \& Education, 43(1), 5-16.

Talua R. M., Pelingon, J. C. \& Verecio, R. L. (2016). Socio-Demographic Profile, Attitude Toward ICT, Computer Self-Efficacy and Level of ICT Competency of Elementary Grades. e-Proceeding of the Social Sciences Research ICSSR 2016, Kuala Lumpur, MALAYSIA.

Tomei, L. A. (2005). Taxonomy for the technology domain. USA: Information Science Publishing.

UNESCO (2002) Information and Communication Technology in Education-A Curriculum for Schools and Programme for Teacher Development. Paris: UNESCO.

VCAA (2002). E-merging: Perspectives on Information and Communications Technology - Teaching and Learning in the VCE. Melbourne: Victorian Curriculum and Assessment Authority

WAEC Registrar's Annual Report to Council on April 1, 2009 to March 31, 2010.

Yildirim, S. (2007). Current Utilization of ICT in Turkish Basic Education Schools; A Review of teacher's ICT use and Barriers to Integration. International Journal of Instructional Media, 34 (2), 171-86.

Yuen, A., \& Ma, W. (2002). Gender differences in teacher computer acceptance. Journal of Technology and Teacher Education, 10 (3), 365

Zalzadeh, E. (2006). A survey on the ICT utilization by the Yazd University faculty members. Ketabdari, 40 (2), 9-20. 